\title{
EFFECT OF REWARD, PUNISHMENT AND COMMUNICATION ON THE EMPLOYEE PERFORMANCE OF THE FASHION DIVISION AT PT. MITRA ADI PERKASA TBK SURABAYA
}

\author{
Debbynia Nur Rika Sari ${ }^{1}$, Bayu Airlangga Putra² ${ }^{2}$ Mochammad Arif ${ }^{3}$ \\ debbynia.rika@gmail.com ${ }^{1}$,bayu.airlangga71@gmail.com ${ }^{2}$, muchamad.arif@ narotama.ac.id ${ }^{3}$ \\ Narotama University, Faculty of Economics and Business, Departement of Management \\ Arief Rachman Hakim Street Number 51, Sukolilo, Surabaya60117 1,2,3
}

\begin{abstract}
This study aims to determine the effect of simultaneous and partial reward, punishment and communication on the performance of fashion division employees at PT. Mitra Adi Perkasa Tbk Surabaya. This research is quantitative research. Population and sample based on questionnaire distribution to the performance of fashion division employees at PT. Mitra Adi Perkasa Tbk Surabaya was taken as many as 75 respondents. Data collection techniques using interviews, observation and questionnaires. The data analysis used is reliability test, validity test, classic assumption test and multiple linear analysis test. The results of the study simultaneously and partially reward, punishment and communication have a significant effect on the performance of fashion division employees at PT. Mitra Adi Perkasa Tbk Surabaya because of its significance $<0.005$
\end{abstract}

Keywords: Reward, Punishment and Communication, Employee Performance.

\section{INTRODUCTION}

In the world of work today is highly demanded to create effective and efficient employee performance to be able to advance the company. Companies must be able to build and improve the performance of their employees to increase the competitiveness of companies against the company's competitors so that the company can survive in a world of increasingly fierce competition. There are several factors that influence the success of the company, one of the important factors is human resources, because HR itself is a driving force from the whole level of planning to evaluation that is able to utilize other resources owned by the company.

An emerging phenomenon in the fashion industry in the current era that is growing rapidly, one of which is the clothing sector that can support one's lifestyle. PT.Mitra Adi Perkasa, Tbk Surabaya is a retail company that works with potential foreign designers to introduce and sell a variety ofproducts imported including clothing and accecorise. Many failures in the organization are caused by lack of proper communication by the actors in the organization. It is known that the instability of employee performance due to work partners is lack of communication resulting in ineffective and inefficient employee work time communication that is not blamed as the cause of uncooperative teamwork in handling problems that affect commitment at PT. Mitra Adi Perkasa, Tbk for example lack of communication between work partners so that there are often problems in the store (example: selling items that should not have been launched yet but already sold first so that it greatly influences subsequent sales due to goods that have not yet been sold first and misinformed about the promo being carried out distore).

Therefore, increasing HR is very important to improve employee performance. To improve employee performance needs to be given a reward in order to encourage employees to perform optimally for example (giving target achievement rewards for each store every month, as well as achieving reward sales for vouchers held every 6 months). However, in giving the reward, it cannot be said that it can arouse employee morale at PT. Mitra Adi Perkasa, Tbk. This happened because of frequent sudden changes in targets and voucher competitions held in all PT. Mitra Adi Perkasa, Tbk stores throughout Indonesia. So that employees have difficulty getting these rewards.

In addition to giving rewards, the company must also pay attention to the Punishment given to PT. Mitra Adi Perkasa, Tbk employees due to frequent employees giving out SOPs (eg coloring hair, working hours are not always on time, sleeping in the bar at recess, and entering customer member points to private employees themselves) and lack of understanding of store employees who are less alert in carrying out their respective job disks. The purpose of Punishment is to motivate in improving performance but some employees actually hold a grudge when the punishment is obtained which will affect the emotions of employees becoming unstable and can reduce the quality of employee performance. 
So based on these phenomena came the idea to analyze whether Reward, Punishment and Communication affect both partially and simultaneously the performance of an employee at PT. ADI PERKASA TBK PARTNER in Surabaya.

\section{Research question}

Based on the background of the research above, the formulation of the problem in this study is as follows: :

1. Does the reward have a significant effect partially on the performance of fashion division employees at PT. Mitra Adi Perkasa Tbk Surabaya?

2. Does punishment have a significant effect partially on the performance of fashion division employees at PT. Mitra Adi Perkasa Tbk Surabaya?

3. Does communication have a significant effect partially on the performance of fashion division employees at PT. Mitra Adi Perkasa Tbk Surabaya?

4. Whether reward, punishment and communication have a significant effect simultaneously on the performance of fashion division employees at PT. Mitra Adi Perkasa Tbk Surabaya?

\section{THEORETICAL FRAMEWORK}

\section{Reward}

Reward is an appreciation of the effort to get the professional labor in accordance with the demands of office required of a business activity of organizing, planning, use, and maintenance of the workforce to be able to carry out its duties effectively and efficiently.

\section{Punishment}

Punishment is the penalty which aims to improve the performance of employee violators, maintain applicable regulations and provide lessons to offenders (Mangkunegara (2013) in Kentjana and Nainggolan (2018).

\section{Communication}

Communication is defined as the performance and interpretation of messages between communication units that are part of an organization (Wayne, 2001 : 143) in Marta and Triwijayanti (2016).

\section{Employee Performance Employee}

performance is the result of a process that refers to and is measured over a certain period of time based on predetermined provisions and agreements (Edison et al, 2016: 190).

\section{Previous Research}

Tangkuman, Tewal, Trang(2015) The results of the analysis of research simultaneously assessing performance, reward and punishment, have a significant effect on employee performance. Partially the evaluation of performance, reward and Punishment partially has a significant effect on employee performance. Suak, Adolfina (2017).

The results of the analysis show that the correlation between reward and punishment on employee performance is very weak. Simultaneous hypothesis testing states that reward and punishment do not have a significant effect on employee performance. Hypothesis testing partially shows that reward and punishment also have no significant effect on employee performance. Suryadilaga, Musadieq, Nurtjahjono (2016) The results of the analysis show that there is a simultaneous significant effect of Employee Reward and Punishment Employee variables on Employee Performance. In addition, it can also be seen that there is a significant effect partially from Employee Reward and Punishment Employee variables on Employee Performance. (Alam, 2013) The results of the study show that together (simultaneous) independent variables have a significant influence on the nonindependent variables. Thus, the first hypothesis which states communication, motivation and work discipline together have a significant effect on the performance of employees of the Central Sulawesi Provincial Education Quality Assurance Agency, stated proven. (Utami, 2010) The results of the analysis show that leadership, motivation, and work environment variables have a positive and significant effect on employee performance, but communication variables have not significantly affected employee performance. Hypothesis testing uses the Multiple Linear Regression test. (Nnaji-Ihedinmah, 2015) In this study states that from empirical results there is a relationship between reward and employee performance and there are significant differences in the effect of intrinsic and extrinsic rewards on employee performance. Ndungu (2017) Results show a significant positive relationship between appreciation and recognition, with employee performance. In addition a very positive and significant relationship also occurs observed between job performance and independent variables (extrinsic rewards, intrinsic and financial rewards, award awards, work environment and leadership style). (Salawati, 2015) The results and conclusions of the influence of punishment and employee work discipline simultaneously have no 
significant effect on employee work performance, so some penalties have a significant effect on employee work performance but employee discipline partially has a positive but not significant effect on employee work performance at PT Bank Sulut Tomohon. The management of Bank Sulut Tomohon must recruit qualified and qualified employees to contribute to the achievement of the company. (Kuncowati \& Rokhmawati, 2018) According to the results of the research and description of the data displayed, communication and work discipline have a significant influence on employee performance both simultaneously and partially. (Femi, 2014) The results of this study reveal that a relationship exists between effective communication and worker performance, productivity, and commitment. Learning is recommended that managers need to communicate with employees regularly to increase commitment workers and performance

\section{METHODOLOGY}

Type of Research

This type of research is causal research (looking for causation by using hypotheses), where the object of this research is case studies conducted on employee performance in the fashion division at PT. Mitra Adi Perkasa, Tbk. This study will use a quantitative approach, according to Sugiyono (2016) quantitative method is a scientific approach that views a reality that can be classified, concrete, observable, and measurable, the relationship of variables is causal where the research data is in the form of numbers and the analysis uses statistics. The independent variables in this study are reward, punishment and communication and the dependent variable of employee performance. The purpose of this study is more towards the results of generalizations, explaining phenomena in a more measurable manner and various evidences to be found. Data collection to obtain results of discussion, analysis and conclusions that can be accounted for.

\section{Place and Time of Research}

This research was conducted at PT. Mitra Adi Perkasa, Tbk. The time of the study was conducted from September 2018 - January 2019.

\section{Conceptual Framework}

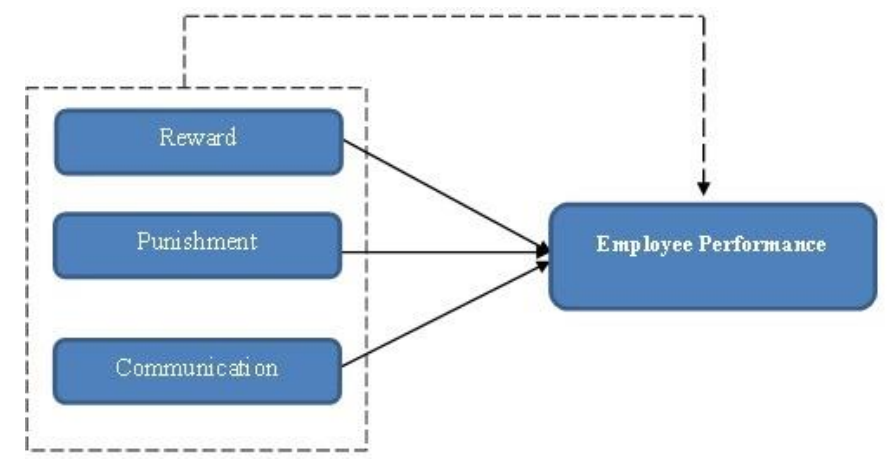

Source: Self-processed, 2019

\section{Population and Sample}

The population in this study was the performance of the fashion division employees at PT. Mitra Adi Perkasa, Tbk, which amounted to 75 employees. Samples are part of the number and characteristics possessed by the population (Sugiyono, 2016). In this study the sampling technique used is saturated sampling, saturation is a sampling technique if all members of the population are used as samples or research who want to make generalizations with errors which is very small. Another term saturated sample is a census, where members of the population are sampled (Sugiyono, 2016). Based on these opinions, the research sample is the performance of the fashion division employees at PT. Mitra Adi Perkasa, Tbk, which amounted to 75 employees

\section{Data Collection Method}

The data sources used in this study used primary data and secondary data. Primary data are data obtained directly from the object of research, namely the fashion division employees at PT. Mitra Adi Perkasa, Tbk. And secondary data, researchers get from data that has been processed by third parties, through books, libraries, libraries, and sources from the internet.

\section{Operational Definition of Research Variable}

\section{1) X1: Reward}

Reward is a form of business appreciation to get a professional workforce in accordance with the demands of the position required an effort to organize, plan, use, and maintain labor to be able to carry out tasks effectively and efficiently. 


\section{2) X2: Punishment}

Punishment is the threat of punishment that aims to improve employee violator performance, maintain applicable regulations and provide lessons to offenders.

3) X3: Communication

Communication is defined as the performance and interpretation of messages between communication units that are part of an organization

4) Y: Employee Performance employee.

Performance is the result of a process that refers to and measured over a certain period of time based on the provisions and agreements that have been previously set.

\section{Data Analysis Method}

Reliability and Validity Test

Reliability Test actually is a tool for measuring a questionnaire which is an indicator of a variable or construct. A questionnaire is said to be reliable or reliable if someone's answer to a question is consistent or stable over time. Questionnaire items are said to be reliable (feasible) if cronbach's alpha $>0.06$ and said to be unreliable if cronbach's alpha <0.06. (Ghozali, 2012: 47). Validity test is used to measure the validity of a questionnaire. A questionnaire is said to be valid if the questionnaire is able to reveal something that will be measured by the questionnaire. Testing this validity using Pearson Correlation is by calculating the correlation between the values obtained from the questions. A question is said to be valid if the level of significance is below 0.05. (Ghozali, 2012: 52)

\section{Multiple Regression AnalysisModel}

The data analysis technique used in this study is multiple regression analysis techniques. This analysis is intended to determine the effect of reward (X1), punishment (X2) and communication (X3) on employee performance (Y):

$Y=a+b 1 X 1+b 2 \times 2+b 3 \times 3+e$

Description:

$\mathrm{Y}=$ Employee performance

$\mathrm{a}=$ Value of constant

b1, b2, b3 = Variable Coefficient

$\mathrm{X} 1=$ reward

$\mathrm{X} 2=$ punishment

$\mathrm{X} 3=$ communication

$\mathrm{e}=$ error term

\section{RESULT AND DISCUSSION}

\section{Result}

Reliability and Validity

Based on research, the alpha cronbanch value is 0.919 , which means that it is above the acceptance limit of 0.6 because the research instrument for the relationship between variables shows good consistency and acceptable data. Based on the research value of the correlation index for the relationship between the independent variables (reward, punishment, and communication) and the dependent variable (Employee Performance) below the significant level of 5\% (0.05). Therefore, the data is considered valid.

\section{Multiple Linear Regression Result}

Table 1. Multiple Linear Regression Result

\begin{tabular}{|c|c|c|c|c|c|c|}
\hline \multirow{2}{*}{\multicolumn{2}{|c|}{ Model }} & \multicolumn{2}{|c|}{ Unstandardized Coefficients } & $\begin{array}{l}\text { Standardized } \\
\text { Coefficients }\end{array}$ & \multirow[b]{2}{*}{$\mathrm{T}$} & \multirow[b]{2}{*}{ Sig. } \\
\hline & & B & Std. Error & Beta & & \\
\hline \multirow[t]{4}{*}{1} & (Constant) & .017 & 2.287 & & .008 & .994 \\
\hline & TOTAL_X1 & .242 & .071 & .240 & 3.397 & .001 \\
\hline & TOTAL_X2 & .369 & .061 & .465 & 6.009 & .000 \\
\hline & TOTAL_X3 & .476 & .105 & .350 & 4.530 & .000 \\
\hline
\end{tabular}

a. Dependent Variable: TOTAL_Y 
Source: SPSS Output, 2019.

Regression equation models that can be written from these results in the form of standard form regression equations are as follows:

$$
Y=0,017+0,242 . X 1+0,369 . X 2+0,476 . X 3+e
$$

\section{Constants}

The value of the 0.017 constant indicates that if the independent variable is in a constant or constant condition, then the value of the employee's performance $(\mathrm{Y})$ is 0.017 units

2. Coefficient value Reward (X1)

Coefficient value Reward (X1) shows a value of 0.242 and has a positive regression coefficient, it shows a direct influence between the variable reward (X1) and employee performance (Y) which means that if there is an addition to thevariable reward (X1) of 1 unit, then the employee's performance (Y) will increase by 0.242 units. Assuming other independent variables are in a constant or constant condition.

3. Value of coefficient punishment (X2)

Value Punishment (X2) shows a value of 0.369 and has a positive regression coefficient, it shows a direct influence between thevariable punishment (X2) and employee performance (Y) which means that if there is an addition to thevariable punishment (X2) as many as 1 unit, then employee performance (Y) will increase by 0.369 units. Assuming other independent variables are in a constant or constant condition.

4. Communication coefficient value (X3)

Communication value (X3) shows a value of 0.476 and has a positive regression coefficient sign, it shows a directional influence between communication variables (X3) with employee performance (Y) which means that if there is an addition to the communication variable (X3) by 1 unit, then the employee's performance (Y) will increase by 0.476 units. Assuming other independent variables are in a constant or constant condition.

\section{Result of R Square}

Table 2. Result of R Square

\begin{tabular}{|l|r|r|r|r|r|}
\hline \multicolumn{1}{|c|}{ Model Summary $^{\mathbf{b}}$} \\
\hline 1 & $\mathrm{R}$ & R Square & Adjusted R Square & $\begin{array}{c}\text { Std. Error of the } \\
\text { Estimate }\end{array}$ & Durbin-Watson \\
\hline
\end{tabular}

a. Predictors: (Constant), TOTAL_X3, TOTAL_X1, TOTAL_X2

b. Dependent Variable: TOTAL_Y

The value of Adjusted R Square is 0.692, which means that all independent variables: reward, punishment and communication have a positive relationship with employee performance.

\section{Test of Classical Assumption}

\section{1) MulticollinearityMulticollinearity}

Testtest in this study can be seen as follows :

Table 3

Multicollinearity Test

\begin{tabular}{|l|c|c|c|}
\hline \multirow{2}{*}{ Variabel } & \multicolumn{2}{|c|}{ Collinearity Statistics } & \multirow{2}{*}{ Keterangan } \\
\cline { 2 - 3 } & Tolerance & VIF & Bebas multikoleniaritas \\
\hline Reward $\left(\mathrm{X}_{1}\right)$ & 0,836 & 1,197 & Bebas multikoleniaritas \\
Punishment $\left(\mathrm{X}_{2}\right)$ & 0,694 & 1,441 & Bebas multikoleniaritas \\
Komunikasi $\left(\mathrm{X}_{3}\right)$ & 0,695 & 1,440 & . \\
\hline
\end{tabular}

Source: SPSS Output Data

On Table 4.18 it can be seen that the model regression does not experiencedisorders multicollinearity. This can be seen in thevalue tolerance of each independent variable greater than 0.1 . The VIF calculation results also show that the VIF value of each independent variable is less than 10. So it can be concluded that there is no multicollinearity between independent variables in the regression model.

\section{2) Heteroscedasticity}

Test The Heteroskedactivity test graph can be explained in the following figure : 


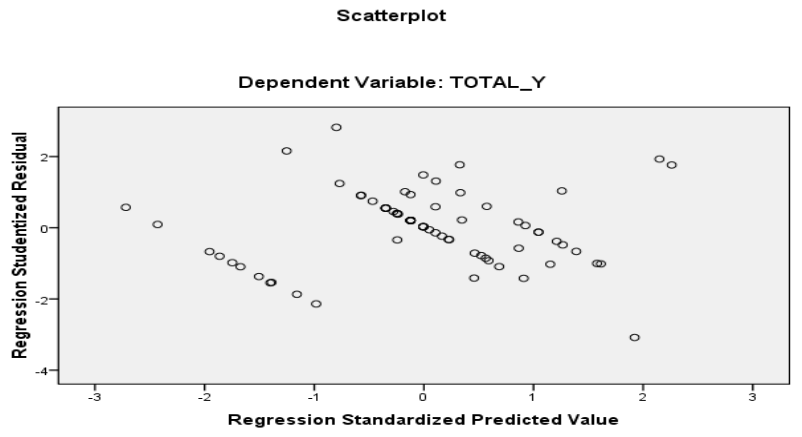

Figure 1

Heteroskedactivity

Source: Data SPSS Output

Based on the graph above it can be seen that the distribution of data is irregular and does not form a specific pattern, and is spread over and below the number 0 on the $\mathrm{Y}$ axis, so it can be concluded that in this regression model there is no problem of heteroscedasticity.

\section{3) Normality Test The}

Graph is presented in the following figure 4.1:

\section{Normal P-P Plot of Regression Standardized Residua}

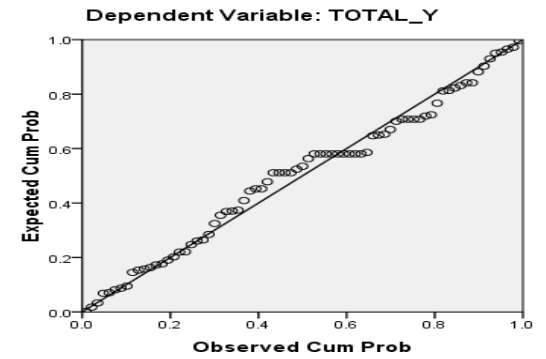

Figure 2

\section{Results of Normality Test Calculation}

Source: SPSS Output Data

Based on the above graph shows that all existing data are normally distributed, because all data spreads form diagonal straight lines then the data meets normal assumptions or follow the normality line.

\section{Hypothesis Testing}

\section{F-Test The}

F-test is used to determine all effects of all independent variables on the dependent variable. This test is done by comparing the Fcount value with Ftable value at $\alpha=0.05$.

Table 4.F-Test Results

ANOVA $^{\mathrm{b}}$

\begin{tabular}{|l|r|r|r|r|r|}
\hline Model & Sum of Squares & Df & Mean Square & F & Sig. \\
\hline $1 \quad$ Regression & 325.655 & 3 & 108.552 & 56.549 & $.000^{2}$ \\
Residual & 136.291 & 71 & 1.920 & & \\
Total & 461.947 & 74 & & & \\
\hline
\end{tabular}

a. Predictors: (Constant), TOTAL_X3, TOTAL_X1, TOTAL_X2

b. Dependent Variable: TOTAL_Y 
F-test is used to determine all effects of all independent variables on the dependent variable. This test is done by comparing the Fcount value with Ftable value at $\alpha=0.05$. The overall effect of reward, punishment and communication on employee performance is very significant.

T-Test

Table 5. T-Test Result

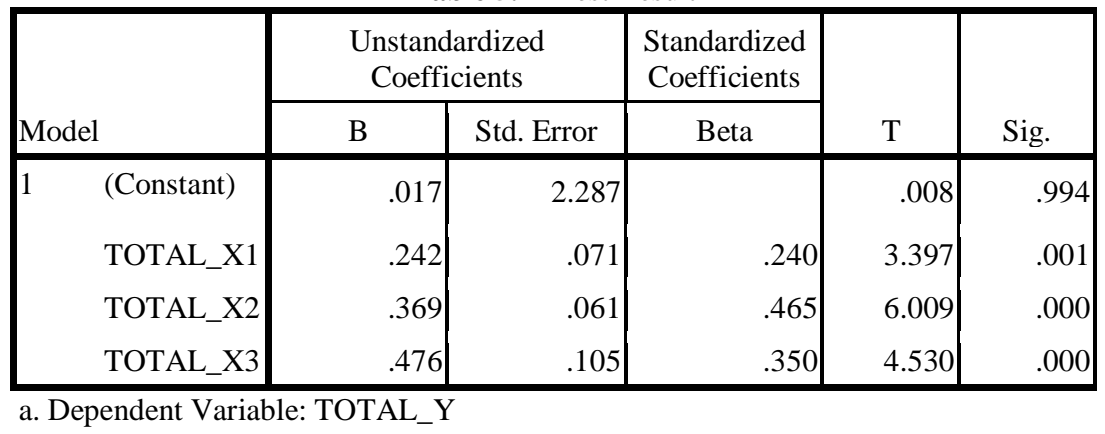

Source: SPSS Output, 2019

1. Table 5 shows that tcount reward (X1) is 3.397 with sig 0.001 smaller than $0.05, \mathrm{H} 0$ is rejected and Ha is accepted. Therefore reward (X1) has a significant influence on Employee Performance

2. Table 5 shows that the $\mathrm{t}$ - punishment (X2) is 6,009 with sig 0,000 smaller than 0.05 , H0 is rejected and $\mathrm{Ha}$ is accepted. Therefore punishment (X2) has a significant effect on Employee Performance

3. Table 5 shows that communication tcount (X3) is 4,530 with sig 0,000 smaller than 0.05 , H0 is rejected and $\mathrm{Ha}$ is accepted. Therefore communication (X3) has a significant influence on Employee

\section{Reward Performance on Employee Performance}

The first hypothesis proposed states that the reward is partially towards the performance of the fashion division employees at PT. Mitra Adi Perkasa, Tbk this has been proven by the value of t test results 3,401.

\section{Punishment on Employee Performance}

The second hypothesis proposed states that punishment is partially towards the performance of fashion division employees at PT. Mitra Adi Perkasa, Tbk. This has been proven by the results of t test value 6,482.

\section{Communication Against Employee Performance}

The third hypothesis proposed states that communication is partially towards the performance of fashion division employees at PT. Mitra Adi Perkasa, Tbk. This has been proven by the results of the t test value of 2,858.

Reward, Punishment and Communication Influence the Employee Performance of the Fashion Division at Pt. Mitra Adi Perkasa, Tbk.

The fourth hypothesis proposed states that reward, punishment simultaneousand communication have a significant effect on the performance of fashion division employees at PT. Mitra Adi Perkasa, Tbk. the result of the test value $\mathrm{F} 55,549$.

\section{CONCLUSION AND RECOMMENDATION}

\section{Conclusion}

Based on the results of the research and analysis that has been done can be stated several things that are the conclusions of this study, namely :

1. The results of this study were obtained from the calculation of SPSS based on the t test,

a. Variable rewards have a partially significant effect on the performance of fashion division employees at PT. Mitra Adi Perkasa Tbk Surabaya where significant value is smaller than 0.05 , which is 0.001 . This shows that the results of the first hypothesis analysis "rewards partially have a significant effect on the performance of fashion division employees at PT. Adi Perkasa Mitra Tbk Surabaya "proved the truth.

b. variables Punishment have a partially significant effect on the performance of fashion division employees at PT. Mitra Adi Perkasa Tbk Surabaya where significant value is smaller than 0.05 , which is 0,000 . This shows that the results of the second hypothesis analysis "Brand trust partially has a significant effect on the performance of fashion division employees at PT. Adi Perkasa Mitra Tbk Surabaya "proved the truth.

c. Communication variables have a significant effect partially on the performance of fashion division employees at PT. Mitra Adi Perkasa Tbk Surabaya where significant value is smaller than 0.05, which is 0,000. This shows that the results of the third hypothesis analysis "communication partially has a significant effect on the performance of fashion division employees at PT. Adi Perkasa Tbk Surabaya partner "proved the truth 
2. The results of this study were obtained from the calculation of SPSS based on the F test, theF valuecalculated obtained was 56.549 greater than Ftable 2.73. This means that Ho is rejected and Hi is accepted, variable reward, punishment and communication simultaneously have a significant effect on the performance of fashion division employees at PT. Mitra Adi Perkasa Tbk Surabaya (Y). This shows that the third hypothesis which reads "reward, punishment and communication simultaneously have a significant effect on the performance of fashion division employees at PT. Mitra Adi Perkasa Tbk Surabaya "is proven empirically.

\section{Recommendation} follows :

Based on the results of the research and conclusions above, the researcher needs to provide suggestions as

1. For that PT. Adi Perkasa Tbk Surabaya partner is expected to get bonuses and benefits to encourage the performance of company employees and have a sense of responsibility in working.

2. For this reason, PT. Adi Perkasa Tbk Surabaya partner is expected to give punishment in the form of warning / warning first, if it continues to make mistakes, then it will be given punishment in accordance with the regulations of PT. Mitra Adi Perkasa Tbk Surabaya.

3. We recommend that PT. Mitra Adi Perkasa Tbk Surabaya is expected to be able to improve the process of information exchange between employees throughout the management line so that good relations are established when completing tasks without any misscomunication.

4. For the next researcher, it is expected to be able to enter and add other variables as independent variables, so that further research that will be carried out will be able to know other variables that greatly affect the performance of fashion division employees at PT. Mitra Adi Perkasa Tbk Surabaya. This is important because of the results of the research that the authors did, it turns out that the independent variable studied consisting of reward, punishment and communication was only able to predict $69.2 \%$ of the performance of the fashion division employees at PT. Mitra Adi Perkasa Tbk Surabaya.

\section{REFERENCES}

Alam, S. (2013). Pengaruh Komunikasi, Motivasi, dan Disiplin Kerja Terhadap Kinerja Pegawai Lembaga Penjaminan Mutu Pendidikan. (Juli), 135-145.

Femi, A. F. (2014). The Impact of Communication on Workers' Performance in Selected Organisations in Lagos State, Nigeria. IOSR Journal of Humanities and Social Science, 19(8), 75-82. https://doi.org/10.9790/083719827582

Kentjana, \& Nainggolan. (2018). Pengaruh Reward Dan Punishment Terhadap Kinerja Karyawan Dengan Motivasi Sebagai Variabel Intervening (Studi Kasus Pada Pt. Bank Central Asia Tbk.). National Conference of Creative Industry, (September), 5-6. https://doi.org/10.30813/ncci.v0i0.1310

Kuncowati, H., \& Rokhmawati, H. N. (2018). The Influence of Communication and Work Discipline on the Employee Performance (A Case Study of Employee Performance of Dwi Arsa Citra Persada Foundation in Yogyakarta \& Indonesia). Researchers World : Journal of Arts \& Science and Commerce(RWJASC), IX(2), 06. https://doi.org/10.18843/rwjasc/v9i2/02

Mamangkey, Tumbel, U. (2015). (2015). The Effect Of Training, Experience And Work Environment Of The Performance. 3(1), 737-747.

Marta, \& Triwijayanti. (2016). Pengaruh Budaya Organisasi dan Komunikasi Organisasi terhadap Kinerja Karyawan PT. X. BISMA (Bisnis Dan Manajemen), 8(2), 218. https://doi.org/10.26740/bisma.v8n2.p218236

Ndungu (2017). (2017). The Effects of Rewards and Recognition on Employee Performance in Public Educational Institutions: A Case of Kenyatta University, Kenya. 17(1).

Nnaji-Ihedinmah, N. C. (2015). Effect of Rewards on Employee Performance in Organizations: A Study of Selected Commercial Banks in Awka Metropolis. Effect of Rewards on Employee Performance in Organizations: A Study of Selected Commercial Banks in Awka Metropolis, 7(4), 2222-2839. https://doi.org/10.1177/0094582X14544108

Salawati. (2015). The Effect Of Punishment And Employee Discipline On Employee Work Achievement At Bank Sulut Tomohon. EMBA, 3(1), 358-366. https://doi.org/10.1145/3132847.3132886

Tangkuman, Tewal, T. (2015). (2015). Karyawan Pada Pt . Pertamina ( PERSERO ). 3(2), 884-895.

Utami, S. S. (2010). Pengaruh kepemimpinan, motivasi, komunikasi dan lingkungan kerja terhadap kinerja pegawai kecamatan jumantono kabupaten karanganyar. Manajemen Sumberdaya Manusia, 4(1), 58-67. Retrieved from http://ejurnal.unisri.ac.id/index.php/Manajemen/article/view/89/62

Edison,2016. Manajemen Sumber Daya Manusia, Bandung : Alfabeta

Suryadilaga, Rendra Maulana., Mochammad Al Musadieq., Gunawan Eko Nurtjahjono. 2016. Pengaruh Reward dan Punishment Terhadap Kinerja (Studi Pada Karyawan PT. Telkom Indonesia Witel Jatim Selatan Malang). Jurnal Administrasi Bisnis (JAB), Vol. 39, No. 1, Oktober 2016. 
Sugiyono. (2016). Metode Penelitian Kuantitatif Kualitataif dan Kombinasi (Mixed Methods). Bandung: Alfabeta. Ghozali, Imam. 2012. Aplikasi Analisis Multivariate dengan Program IBM SPSS. Yogyakarta: Universitas Diponegoro 